*alls View/Frint Document Cover Sheet tose

This document was retrieved from the Boeing ISEARCH System.

Accession \#: D196069738

Document \#: SD-WM-TP-207

Title/Desc:

TANK 241C103 TANK CHARACTERIZATION PLAN 


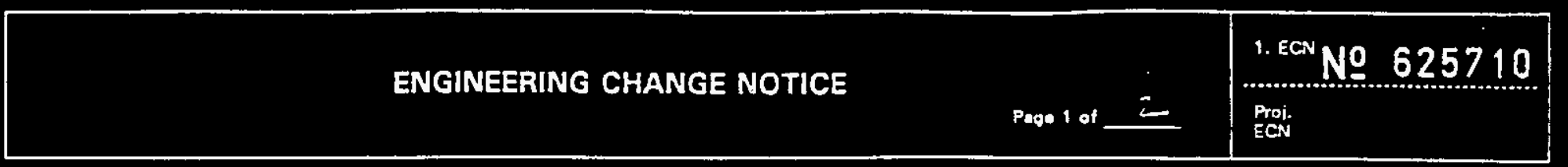

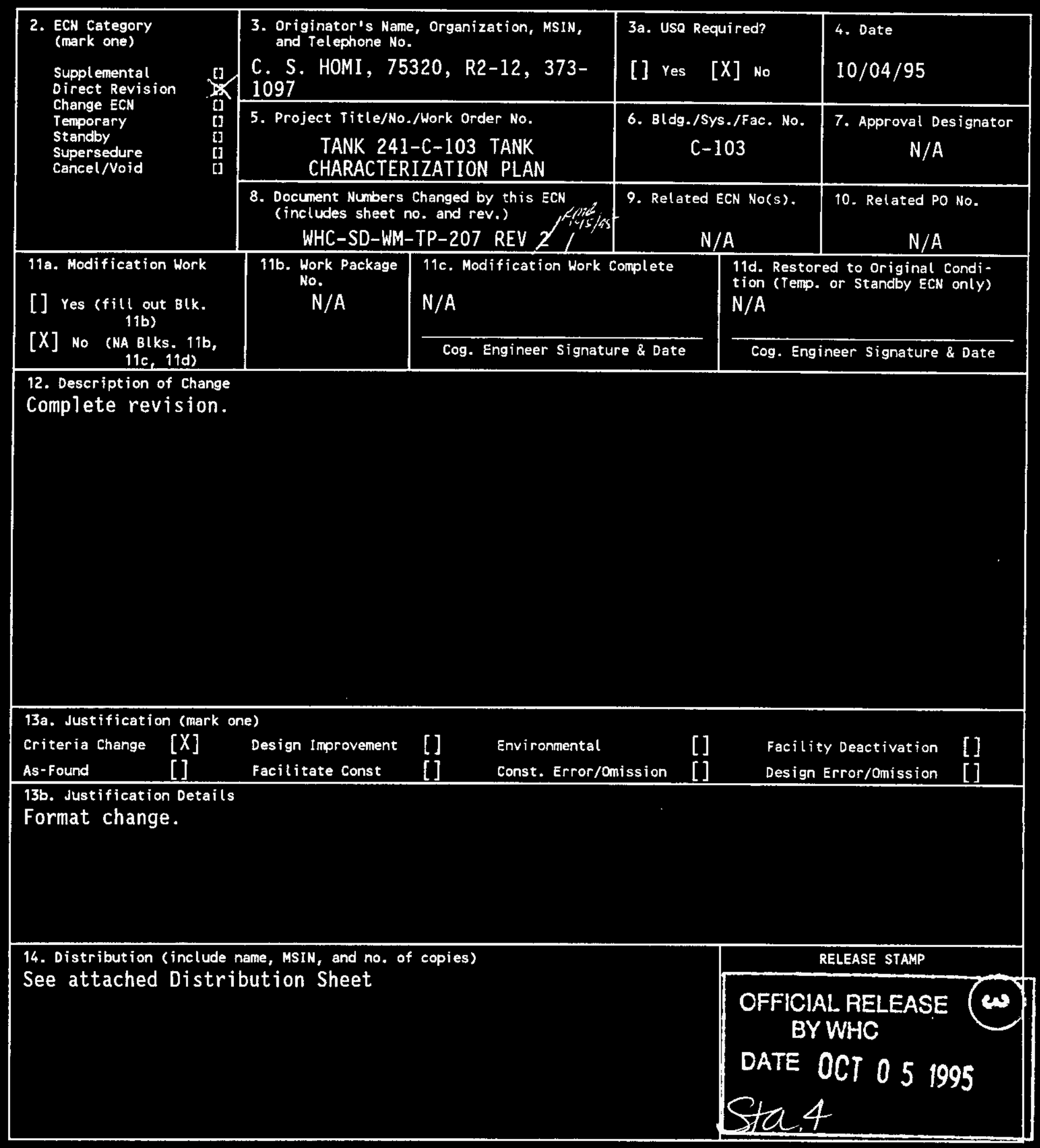

A-7900-013-2 (11/94) GEF095 


\section{RELEASE AUTHORIZATION}

Document Number: $\quad$ WHC-SD-WM-TP-207, REV 2

Document Title: Tank 241-C-103 Tank Characterization Plan

Release Date: $\quad 10 / 5 / 95$

This document was reviewed following the procedures described in WHC-CM-3-4 and is:

\section{APPROVED FOR PUBLIC RELEASE}

WHC Information Release Administration Specialist:

$<$
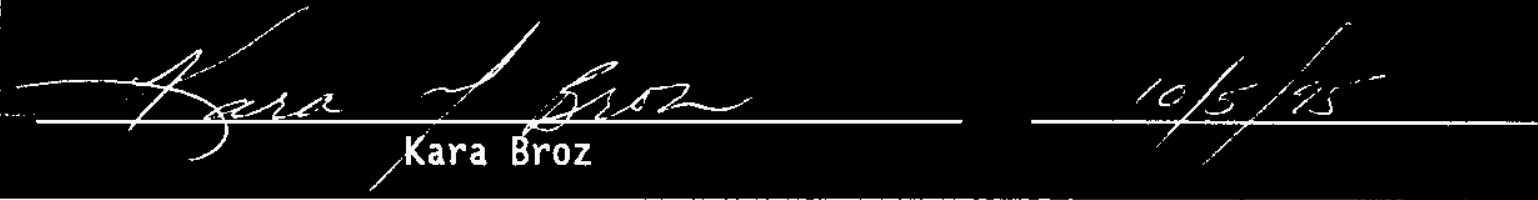

TRADEMARK DISCLAIMER. Reference here in to any specific commercial product, process, or service by trade name, trademark, manufacturer, or otherwise, does not necessarily constitute or imply its endorsement, recommendation, or favoring by the United States Government or any agency thereof or its contractors or subcontractors.

This report has been reproduced from the best available copy. Available in paper copy. Printed in the United States of America. To obtain copies of this report, contact:

Westinghouse Hanford Company - Document Control Services

P.0. Box 1970, Mailstop H6-08, Richland, WA 99352

Telephone: (509) 372-2420; Fax: (509) 376-4989 
2. Title

TANK 241-C-103 TANK CHARACTERIZATION PLAN

5. Key Words

CHARACTERIZATION, GENERAL SAFETY ISSUES, SPECIFIC

SAFETY ISSUES, INFORMATION REQUIREMENTS, PRIORITY
3. Number

WHC-SD-WM-TP-207

6. Author

Name:

Name:

signature

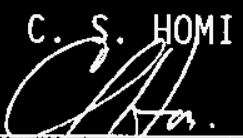

$10 / 4 / 95$

Organization/Charge Code

$75320 / N 4 G 6 A$

4. Rev No. 2

2

\section{Abstract}

This document is a plan that identifies the information needed to address relevant issues concerning short-term and long-term safe storage and long-term management of Single-Shell Tank (SST) 241-C-103.

8.

RELEASE STAMP

OFFICIAL RELEASE BYWHC

DATE 
(2) Title

TANK 241-C-103 TANK CHARACTERIZATION PLAN

CHANGE CONTROL RECORD

\begin{tabular}{|c|c|c|c|}
\hline \multirow{2}{*}{ (3) Revision } & \multirow{2}{*}{ (4) Description of Change - Replace, Add, and Delete Pages } & \multicolumn{2}{|c|}{ Authorized for Release } \\
\hline & & (5) Cog. Engr. & (6) Cog. Mgr. Date \\
\hline 0 & $\begin{array}{l}\text { (7) WHC-SD-WM-TP-207, REV. O, EDT 159074, } \\
\text { October 3, 1994 }\end{array}$ & & \\
\hline 1 & Revised in its entirety, ECN 617829 & & \\
\hline $2 R E$ & Complete revision to new format, ECN 625710 & Elta & $x+3=144-18$ \\
\hline & & & \\
\hline & & & \\
\hline & & & \\
\hline & & & \\
\hline & & & \\
\hline & & & \\
\hline & & & \\
\hline & & & \\
\hline & & & \\
\hline & & & \\
\hline & & & \\
\hline & & & \\
\hline & & & \\
\hline & & & \\
\hline & & & \\
\hline & & & \\
\hline & & & \\
\hline & & & \\
\hline & & & \\
\hline & & & \\
\hline & & & \\
\hline & & & \\
\hline & & & \\
\hline & & & \\
\hline . & & & \\
\hline
\end{tabular}




\title{
Tank 241-C-103 \\ Tank Characterization Plan
}

\author{
C. S. Homi \\ Westinghouse Hanford Company
}

Date Published

October 1995

Prepared for the U.S. Department of Energy

Office of Environmental Restoration and

Waste Management

$\begin{array}{ll}\text { Westinghouse } & \text { P.O Box } 1970 \\ \text { Hanford Company } & \text { Richland, Washington }\end{array}$

Management and Operations Contractor for the

U.S. Deparment of Energy under Contrect DE.ACO6.87FL 10930 


\section{TABLE OF CONTENTS}

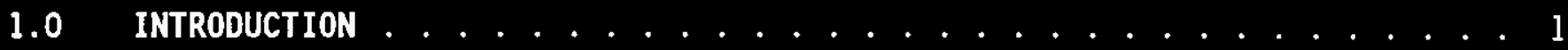

2.0 PROGRAM ELEMENTS REQUIRING INFORMATION FOR 241-C-103 . . . . . . . . . 2

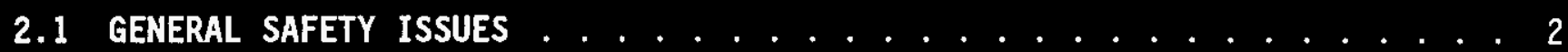

2.2 SPECIFIC SAFETY ISSUES . . . . . . . . . . . . 2

2.2.1 Ferrocyanide .. . . . . . . . . . . . . . . . 2

2.2.2 Organic . . . . . . . . . . . . . . . . . . 2

2.2.3 High Heat . . . . . . . . . . . . . . . . . . . . 2

2.2.4 Flammable Gas . . . . . . . . . . . . . . . . . . . 2

2.2.5 Vapor ............................. 3

2.2 .6 Criticality . . . . . . . . . . . . . . . . . . . 3

2.2.7 Screening Approach Evaluation ................. 3

2.3 CONTINUING OPERATIONS . . . . . . . . . . . . . 3

2.2.1 Compatibility/Stabilization ................ 3

2.2.2 Evaporator ....................... 3

2.4 DOUBLE-SHELL TANK WASTE ANALYSIS PLAN . . . . . . . . . 3

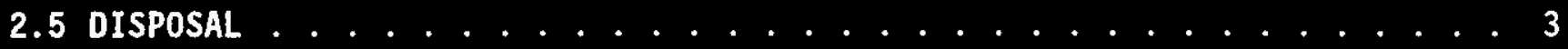

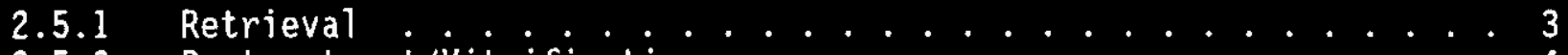

2.5.2 Pretreatment/Vitrification ........... 4

2.6 HISTORICAL MODEL EVALUATION . . . . . . . . . . . . 4

3.0 HOW INFORMATION WILL BE OBTAINED ............... 4

4.0 PRIORITY OF INFORMATION REQUIREMENTS . . . . . . . . . . 5

5.0 WHEN INFORMATION IS NEEDED $\ldots \ldots \ldots \ldots \ldots$

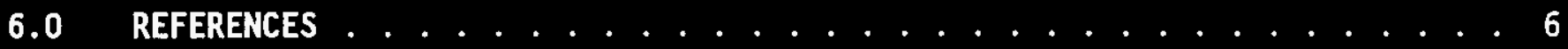

\section{LIST OF TABLES}

Table 4-1: Integrated DQO Requirements ............ 5 
WHC-SD-WM-TP-207, REV 2

\section{LIST OF ABBREVIATIONS}

$\begin{array}{ll}\text { C-103 } & \text { Tank 241-C-103 } \\ \text { DQ0 } & \text { Data Quality Objective } \\ \text { HTCE } & \text { Historical Tank Content Estimate } \\ \text { DSSF } & \text { Double She11 Slurry Feed } \\ \text { NCPLX } & \text { Non-complexed } \\ \text { SST } & \text { Single-She1] Tank } \\ \text { SUMMA } & \text { Trademark of Molectrics, Inc. } \\ \text { TCP } & \text { Tank Characterization P1an } \\ \text { TOC } & \text { Total Organic Carbon } \\ \text { USQ } & \text { Unreviewed Safety Question } \\ \text { WHC } & \text { Westinghouse Hanford Company }\end{array}$




\subsection{INTRODUCTION}

This Tank Characterization Plan (TCP) identifies the information needed to address relevant issues concerning short-term and long-term safe storage and long-term management of Single-She11 Tank 241-C-103 (C-103). It should be understood that the various needs and issues surrounding tank $\mathrm{C}-103$ are evolving as new information about the tank is uncovered. As a result of this progression, this Tank Characterization Plan addresses only the issues that, to this date, have been identified. It is expected that deviations from this plan may occur as additional issues or needs arise which impact the management of SST C-103. As necessary, this Tank Characterization Plan will be revised to reflect those changes or deviations.

Tank C-103 was constructed between 1943 and 1944 and was put into service in August 1946. Initially tank $C-103$ recejved metal waste from the cascade overflow of tank C-102. The cascade of waste from $\mathrm{C}-102$ ended in 1953. During the third quarter of 1953, C-103 received supernate from Tank C-109. The metal waste was sluiced for uranium recovery in 1953. From the third quarter of 1953 until the fourth quarter of 1954, tank $\mathrm{C}-103$ received U Plant waste. During the second, third and fourth quarters of 1960, C-103 received PUREX cladding waste. The tank was utilized for cesium recovery from the fourth quarter of 1964 until the second quarter of 1968 . From the first quarter of 1970 until the second quarter of 1976, C-103 received wastewater. Also, during $1970 \mathrm{C}-103$ received $\mathrm{B}$ Plant low level waste, evaporator bottoms and PUREX sludge supernatant. $\mathrm{C}-103$ received $\mathrm{B}$ Plant waste and waste from the evaporator until the fourth quarter of 1977. Strontium sludge was added at this time. Presently, the tank waste is classified as non-complexed. The tank has a $11.4 \mathrm{~kL}$ (3 kgal) 1 ayer of floating organics comprised of $67 \%$ tributyl phosphate (TBP) and $33 \%$ normal paraffin hydrocarbon (NPH). This tank currently contains waste with a total waste volume of $738.2 \mathrm{~kL}$ (195 kgal), which is equivalent to 168.6 centimeters (66.4 inches) of waste as measured from the baseline of the tank. The waste is comprised of $503.5 \mathrm{~kL}$ (133 kgal) of supernate; $11.4 \mathrm{~kL}(3 \mathrm{kgal})$ of unknown waste and $223.4 \mathrm{~kL}(59 \mathrm{kgal})$ of sludge with $503.5 \mathrm{~kL}$ (133 kgal) pumpable liquid remaining (Brevick 1994a).

The tank is categorized as sound and was declared inactive in 1979. Tank C-103 is passively ventilated and is partially isolated. The last photo was taken on July 28, 1987. The 1987 photographic montage is hazy with quite a few color variations present (Brevick 1994b). There appears to be a 1iquid waste layer covering a dark brown mottled surface layer. The montage should be representative of current tank contents although there was a sma11 level adjustment after these photos were obtained. The last solids volume update was obtained on October 22, 1990 (Hanlon 1995).

Samples were obtained from C-103 between September 1974 and May 1987 . Some samples contained solids and some were only liquids but all were primarily sodium nitrate, sodium nitrite and sodium hydroxide. Although it is not part of the sampling data, test conducted on tank condensate in 1987 detected significant quantities of organic solvents which may have led to the failure of the HEPA filters.

This tank is on the Organics Watch List. The tank has an Unreviewed Safety Question (USQ) because of the potential consequences of a radiological release resulting from ignition and/or volatile reaction of the organic constituents contained within the tank. Near-term sampling and analysis activities are focused on either verification of the watchlist tank status, identification of any new safety issues, changing the Watch List status, or resolving the USQ. Should any safety issues be identified additional analysis will occur consistent with the identified issue. 
In addition to the resolution of the safety issues, it is intended that all tank waste will be subject to pretreatment and retrieval to prepare for final storage or disposal. Presently, these long-range plans have yet to be fully identified and are, therefore, not included in this document.

\subsection{PROGRAM ELEMENTS REQUIRING INFORMATION FOR TANK 241-C-103}

This section identifies the various program elements, and identifies which of these programs require characterization data from tank $\mathrm{C}-103$.

\subsection{GENERAL SAFETY ISSUES}

The Tank Safety Screening Data Quality Objective (Babad et a1. 1995a) describes the sampling and analytical requirements that are used to screen waste tanks for unidentified safety issues. The primary analytical requirements for the safety screening of a tank are energetics, total alpha activity, moisture content, and flammable gas concentration.

\subsection{SPECIFIC SAFETY ISSUES}

\subsubsection{Ferrocyanide}

This tank is not on the Ferrocyanide Watch List and; therefore, no information needs are currently identified for this program element.

\subsubsection{Organic}

This tank is on the Organics Watch List. Sampling and analysis requirements must be performed as per Data Quality Objective to Support Resolution of the Organic Fuel Rich Tank Safety Issue (Babad et a1. 1995b). The analyses employed will determine the TOC, presence of a free organic liquid phase, moisture content and tank temperature.

\subsubsection{High Heat}

This tank is not on the High Heat Watch List and; therefore, no information needs are currently identified for this program element.

\subsubsection{Flammable Gas}

This tank is not on the Flammable Gas Watch List and; therefore, no information needs are currently identified for this program element.

\subsubsection{Vapor}

The tanks currently scheduled to be vapor sampled may be classified into four categories: (1) those tanks which are to be rotary mode core sampled (as a consequence of the rotary sampling system); (2) tanks on the Organic or Ferrocyanide Watch Lists; (3) tanks in $C$ farm; and (4) tank BX-104, due to vapor exposure. Since tank $\mathrm{C}-103$ is categorized in one of the above four groups, information needs must satisfy Data Quality Objectives for Generic In-Tank Health and Safety Vapor Issue Resolution (Osborne 1995). Characterization of the tank headspace is needed to: 1) identify those tanks which can be sampled safely with intrusive equipment without risk of gas ignition; 2) identify and estimate concentrations of toxicologically significant 


\section{WHC-SD-WH-TP-207, REV 2}

compounds present in the tank headspace to establish worker safety precautions; and 3 ) support the startup and operation of the portable exhauster used during rotary-mode core sampling.

\subsubsection{Criticality}

No information separate from that for the general safety issue of tank $\mathrm{C}-103$ are currently identified for this program element. However, if the general safety screening of tank $\mathrm{C}-103$ identifies a potential criticality concern, analyses for fissile materials and neutron absorbers and poisons will be performed as identified in the safety screening data quality objective.

\subsubsection{Screening Approach Evaluation}

The safety screening approach is currently under review. Information is required from key tanks to determine if a revised approach to screening may be adopted, as proposed in Meacham, 1995.

\subsection{CONTINUING OPERATIONS}

\subsubsection{Compatibility/Stabilization}

No information needs are currently identified for this program element.

\subsubsection{Evaporator}

No information needs are currently identified for this program element.

\subsection{DOUBLE-SHELL TANK WASTE ANALYSIS PLAN}

This section does not apply because tank $\mathrm{C}-103$ is a single shell tank.

\subsection{DISPOSAL}

\subsubsection{Retrieval}

Current retrieval needs (Bloom 1995) do not call for test samples to be taken from tank C-103.

\subsubsection{Pretreatment/Vitrification}

Tank $\mathrm{C}-103$ has been identified as a bounding tank for pretreatment/disposal process development (Kupfer 1995).

\subsection{HISTORICAL MODEL EVALUATION}

Bounding tanks and data requirements for historical model evaluations are found in DQO Historical Model Evaluation Data Requirements (Simpson 1995). Tank C-103 has not been identified as a primary bounding tank for any waste type. 


\subsection{HON INFORMATION WILL BE OBTAINED}

The safety screening DQO requires that a vertical profile of the tank waste be obtained from at least two widely spaced risers. This vertical profile may be obtained using core, auger (for shallow tanks), or grab samples. Only a push mode sampling event is scheduled and required. No other sampling is scheduled through fiscal year 1997 (Stanton 1995). The push mode sampling type has been chosen over other sampling modes due to both the depth of the tank (making auger sampling inadequate) and the fact that the surface of tank $\mathrm{C}-103$ is comprised of supernatant and sludge.

The best current estimate of the water content in tank $\mathrm{C}-103$ solids, as determined from the process records, is $70.4 \%$; based on the HTCE (Brevick 1994a). Estimated (Toth et al 1995) water content in tank $\mathrm{C}-103$ sludge is $44.7 \%$ (generated from a model based on sample data from similar tanks). If the variance of water in tanks already sampled and a statistical power curve is used then a minimum of two cores are needed to demonstrate a water content above $17 \%$ at $95 \%$ confidence. Should the measured mean be lower than anticipated or the measured variance higher, additional samples may be required. The TOC contained with in the sludge is estimated (Toth et al 1995) to be $0.3 \%$ (wet basis), which is significantly lower than the level of concern. Two core samples will be requested for this tank and this should meet the requirements for the above parameters.

The best current information indicates that 3 risers are available for sampling of $\operatorname{tank} C-102,4^{\prime \prime}(10.2 \mathrm{~cm})$ riser $R 8$ and $12^{\prime \prime}(30.5 \mathrm{~cm})$ risers R2 and $R 7$. These are the only risers available at this time. Initial information will be taken from these 3 risers and assessed to determine if more samples are required. Alternate sampling methods, installation of a riser or removal of equipment from risers presently considered unavailable, are possible future options. 
WHC-SD-WM-TP-207, REV 2

\subsection{PRIORITY OF INFORMATION REQUIREMENTS}

Vapor sampling is required but, it has not scheduled for this tank at this time. Push mode sampling was completed in February 1995 (Stanton 1995).

Table 4-1: Integrated DQO Requirements

\begin{tabular}{|c|c|c|c|}
\hline $\begin{array}{l}\text { Sampl ing } \\
\text { Event }\end{array}$ & Appl icable DQO & Sampl ing Requirements & Analytical Requirements \\
\hline $\begin{array}{l}\text { Vapor } \\
\text { Sampling }\end{array}$ & $\begin{array}{l}\text { - Health \& Safety Vapor } \\
\text { Issue Resolution DQO }\end{array}$ & $\begin{array}{l}3 \text { SUMMA }{ }^{\circledR} \text { canisters } \\
6 \text { Triple Sorbent Traps } \\
8 \text { Sorbent Trap Systems }\end{array}$ & $\begin{array}{l}\text { Gas Flammability } \\
\text { Gas Toxicity } \\
\text {-Organic Vapors } \\
\text {-Permanent Gases }\end{array}$ \\
\hline $\begin{array}{l}\text { Push Mode } \\
\text { Sampl ing }\end{array}$ & $\begin{array}{l}\text {-Safety Screening DQO } \\
\text {-Organics DQO }\end{array}$ & $\begin{array}{l}\text { Core samples from } 2 \\
\text { risers separated } \\
\text { radially to the maximum } \\
\text { extent possible }\end{array}$ & $\begin{array}{l}\text { Energetics, Moisture, } \\
\text { Total Alpha, Total } \\
\text { Organic Carbon, Free } \\
\text { Organic, SpG }\end{array}$ \\
\hline
\end{tabular}

\subsection{WHEN INFORMATION IS NEEDED}

Data are required for Tank C-103 during FY 1996 for safety screening and to prepare a Tank Characterization Report. 


\section{WHC-SD-WM-TP-207, REV 2}

\subsection{REFERENCES}

Babad, H, K. S. Redus, and J. W. Hunt, 1995a, Tank Safety Screening Data Quality objective, WHC-SD-WM-SP-004, Rev 1, Westinghouse Hanford Company, Richland, Washington.

Babad, H., S. M. B1acker, and K. S. Redus, 1995b, Data Quality Objective to Support Resolution of the Organic Fuel Rich Tank Safety Issue, WHC-SD-WM-DQO-006, Rev. 1, West inghouse Hanford Company, Richland, Washington.

Bloom, G. R., and Q. H. Nguyen, 1995, Characterization Data Needs for Development, Design, and Operation of Retrieval Equipment Developed Through the Data Quality Objective Process, WHC-SD-WM-DQ0-008, Rev. 0, Westinghouse Hanford Company, Richl and, Washington.

Brevick, C. H., 1994a, Historical Tank Content Estimate for the Northeast Quadrant of the Hanford 200 East Areas, WHC-SD-WM-ER-349, Rev. Oa, ICF Kaiser Hanford Company, Richland, Washington.

Brevick, C. H., 1994b, Supporting Document for the Historical Tank Content Estimate for BY Tank Farm, WHC-SD-WM-ER-312, Rev. O, ICF Kaiser Hanford Company, Rich1 and, Washington.

Brown, T. M., S. J. Eberlein, D. A. Dodd, T. J. Kunthara, B. C. Simpson, and N. W. Kirch, Tank Waste Characterization Plan and Basis, 1995, WHC-SD-WM-TA-164, Rev O, Westinghouse Hanford Company, Richland, Washington.

Fowler, K.D., 1995, Data Quality Objectives for the Waste Compatibility Program, WHC-SD-WM-DQO-001, Rev. 1, April 1995, Westinghouse Hanford Company, Richland, Washington.

Hanlon, B.M., 1995, Waste Tank Summary for Month Ending May, 1995, WHC-EP-0182-82, Westinghouse Hanford Company, Richland, Washington.

Homi, C. S., and S. J. Eberlein, 1995, Fiscal Year 1996 Tank Waste Remediation System Tank Waste Analysis Plan, WHC-SD-WM-PLN-101, Rev 0, Westinghouse Hanford Company, Richland, Washington

Kupfer, M. J., W. W. Schultz, and J. T. Slankas, 1995, Strategy for Sampling Hanford Site Tank Wastes for Development of Disposal Technology, WHC-SD-WM-TA-154, Rev. 1, Westinghouse Hanford Company, Richland, Washington.

Meacham, J. E., R. J. Cash, B. A. Pulsipher, and G. Chen, 1995, Data Requirements for the Ferrocyanide Safety Issue Developed through the Data Quality Objectives Process, WHC-SD-WM-DQ0-007, Rev. 1, West inghouse Hanford Company, Richland, Washington.

Osborne, J.W., J.L. Huckaby, E.R. Hewitt, C.M. Anderson, D.D. Mahlum, B.A. Pulsipher, and J.Y. Young, 1995, Data Quality Objectives for Generic In-Tank Health and Safety Vapor Issue Resolution, WHC-SD-WM-DQ0-002, Rev. 1, Westinghouse Hanford Company, Richland, Washington.

Price, D. N., 1994, Rotary Core Vapor Sampling Data Quality Objective, WHC-SD-WM-SP-003, Rev. 0, Westinghouse Hanford Company, Richland, Washington. 
Simpson, B. C., and D. J. McCain, 1995, Historical Model Evaluation Data Requirements, WHC-SD-WM-DQ0-018, Rev. 0, Westinghouse Hanford Company, Richland, Washington.

Stanton, G. A., 1995, Baseline Sampling Schedule, Revision 4.3, (internal memo 74320-95-04, to distribution, March 24), Westinghouse Hanford Company, Richland, Washington.

Toth, J. J., P. G. Heasler, M. E. Lerchen, J. G. Hill, and P. D. Whitney, 1995, Analysis of Organic Carbon and Moisture in Hanford Single-Shell Tank Waste, PNL10360, Pacific Northwest Laboratory, Richland, Washington.

Webb, A. B., J. L. Stewart, D. A. Turner, M. G. Plys, B. Malinovic, J. M. Grigsby, D. M. Camaioni, P. G. Heasler, W. D. Samuels, and J. J. Toth, 1995, Preliminary Safety Criteria for Organic Watch List Tanks at the Hanford Site, WHC-SD-SARR-033, Rev. 0, Westinghouse Hanford Company, Richland, Washington. 